\title{
MENINGKATKAN MOTIVASI BELAJAR ANAK MELALUI METODE PERMAINAN DARI BAHAN BEKAS PADA KELOMPOK B DI KELOMPOK BERMAIN DHARMA MULYA TENGGARONG SEBERANG TAHUN PELAJARAN 2016/2017
}

\author{
Hakimah \\ PG PAUD, FKIP, Universitas Widya Gama Mahakam Samarinda \\ ( imahhakimah83@gmail.com ) \\ Harry Gunawan \\ PG PAUD, FKIP, Universitas Widya Gama Mahakam Samarinda \\ ( harygunawan77@yahoo.co.id)
}

\begin{abstract}
This study concerns with students' low learning motivation issue. At the preliminary observation, only $33.3 \%$ students were reported to be in the good level of learning motivation. Moreover, classroom action research was conducted to reveal the effectiveness of using used materials as teaching aids in terms of promoting students' learning motivation. In this study, the researcher applied two cycles, wherein, each cycle consists of planning, implementation, observation and reflection. Observation and documentation were employed to collect data. Meanwhile, percentage technique was used to analyze the data. In addition, this study involved 30 students of Dharma Mulya Playgroup. The first cycle shows progress with $47 \%$ students reached the passing grade that falls into fair criteria. However, at the second cycle, students' progress in motivation increased, since $85.6 \%$ students had achieved the passing grade and were categorized in very good criteria. In conclusion, using used materials in teaching (as a method of playing) was able to promote learning motivation of Group B at Dharma Mulya Playgroup Tenggarong Seberang.
\end{abstract}

Key Words: learning motivation, used materials, method of playing in teaching.

\section{PENDAHULUAN}

Pendidikan Anak Usia Dini merupakan suatu upaya pembinaan yang diajukan kepada anak sejak lahir sampai dengan usia 6 tahun yang dilakukan melalui pemberian rangsangan pendidikan untuk membantu pertumbuhan dan perkembangan jasmani dan rohani agar anak memiliki kesiapan pendidikan yang akan datang.

Pendidikan Anak Usia Dini sebagai pendidikan diselesaikan sebelum jenjang pendidikan dasar, memiliki kelompok sasaran anak usia 3-6 tahun yang sering di sebut masa emas perkembangan. Disamping itu pada anak usia ini anakanak masih sangat rentan yang apabila penanganannya tidak dapat justru dapat merugikan anak itu sendiri.

Kenyataannya minat belajar anak saat proses belajar mengajar sedang berlangsung belum optimal. Adapaun proses belajar yang terjadi saat ini yaitu bermain sambil belajar seraya belajar 
sambil bermain. Namun pada pengamatan awal motivasi anak kurang hal ini berdasarkan data empiris dari 30 anak, hanya 6 anak (33,33\%) yang memiliki motivasi dalam kategori baik. Dan sisanya 24 anak (66.67\%) memiliki motivasi dalam kategori kurang dan kurang sekali. Karena bermain merupakan realisasi dari perkembangan diri, kehidupan anak dapat tumbuh dan berkembang melalui berbagai kegiatan yang dilakukan anak pada waktu bermain dan melalui pengamatan, anak dapat mengembangkan potensi-potensi yang dimilikinya melalui bermain.Anakanak usia dini tidak membedakan antara bermain, belajar, dan bekerja. Anakanak umumnya sangat menikmati permainan dan akan terus melakukannya dimanapun mereka memiliki kesempatan, sehingga bermain adalah salah satu cara anak usia dini belajar, karena melalui bermainlah anak mampu belajar tentang apa yang mereka ketahui dan pada akhirnya mampu mengenal semua peristiwa yang terjadi disekitarnya.

Tumbuh kembang anak melewati periode sensitif yang merupakan masa awal untuk belajar.Selama periode positif, anak menjadi peka dan mudah tersimulasi oleh aspek-aspek yang berada di lingkungannya. Menjadi hal penting pendidik untuk memahami proses ini. Karena setiap tahapan memperlihatkan sebuah kesempatan yang menguntungkan yang dapat mempengaruhi perkembangan anakanak dalam proses pembelajaran.

Bermain adalah memberikan pengaruh secara langsung terhadap setiap perkembangan anak. Unsur utama dalam perkembangan program pembelajaran bagi anak usia dini adalah bermain. Pendidikan awal di masa kanak-kanak diyakini memiliki peran yang sangat vital bagi pertumbuhan dan perkembangan pengetahuan selanjutnya. Kurikulum bagi anak usia dini haruslah memfokuskan pada perkembangan yang optimal pada seorang anak memilki lingkungan sekitarnya yang dapat menggali berbagai potensi tersebut melalui permainan serta hubungan dengan orang tua, atau orang dewasa lainnya. Program pembelajaran pada anak usia dini memiliki beberapa fungsi antara lain : untuk pengembangan seluruh kemampuan yang dimiliki anak sesuai dengan tahap perkembangannya. Mengenalkan anak pada lingkungan sekitarnya mengembangakan sosialisasi anak, mengenal peraturan dan menanamkan disiplin pada anak-anak dan memberikan kesempatan kepada anak untuk menikmati masa bermainnya. 
Belajar juga merupakan interaktif atau dialog dari antar interaksi, antar potensi internal anak (pikiran, perasaan, pengalaman dan lain-lain) dengan potensi internal itu sendiri atau dengan eksternal lainnya, guru anak didik, fakta dan konsep, adapun fungsi bermainsambil belajar yaitu, anak didik mampu menirukan apa yang dilakukan oleh orang dewasa, melakukan peran dalam kehidupan yang nyata, dapat menyalurkan perasaan yang kuat, mampu memecahkan masalah, mencerminkan hubungan dengan keluarga. Melepaskan dorongan yang tidak bisa diterima, meceritakan pertumbuhan yang optimal.

Proses belajar mengajar yang berlangsung di Kelompok Bermain Dharma Mulya belum mencapai dengan optimal keterbatasan alat-alat permainan edukatif (APE) yang dimiliki. Alat permainan edukatif (APE) sangat menunjang sekali bagi anak-anak Kelompok Bermain Dharma Mulya untuk berlangsungnya proses belajar mengajar sambil bermain seraya bermain sambil belajar.

Proses belajar mengajar, motivasi sangat diperlukan sebab secara optimal yang tidak mempunyai motivasi dalam belajar, tidak akan mungkin melakukan aktivitas belajar. Hal ini merupakan pertanda bahwa sesuatu yang akan dikerjakan itu tidak menyentuh kebutuhannya. Segala sesuatu yang menarik minat orang lain belum tentu menarik orang tertentu selama sesuatu itu tidak bersentuhan dengan kebutuhannya. Seorang anak yang melakukan aktifitas belajar secara terus menerus tanpa dari luar dirinya merupakan motivasi intrinsik yang sangat penting dalam aktivitas belajar.Namun seorang anak yang tidak mempunyai keinginan untuk belajar, dorongan dari luar dirinya merupakan motivasi ekstrinsik yang diharapkan.

Motivasi belajar sangatlah penting bagi anak-anak, diri dan guru, adapun pentingnya bagi anak-anak didik, menginformasikan tentang kekuatan usaha belajar.Mengarahkan kegiatan belajar, semangat belajar, mengedarkan tentang adanya perjalanan belajar. Motivasi belajar juga sangat penting diketahui oleh seorang guru yaitu : membangkitkan bila anak-anak tak semangat belajarnya timbul tenggelam, dan memelihara semangatnya telah kuat untuk mencapai tujuan belajar, sehingga anak-anak tampak merasa jenuh. Merasa segan dan bosan untuk mengikuti kegiatan belajar mengajar dan tidak ada semangat untuk menerima apa-apa yang diberikan oleh gurunya. Tetapi ada juga yang rajin dan bersemangat untuk mengikuti proses belajar mengajar. 
Berdasarkan latar belakang di atas maka landasan dilaksanakannya penelitian dengan judul "Meningkatkan Motivasi Belajar Anak Melalui Metode Permainan dari Bahan Bekas pada Kelompok $B$ di Kelompok Bermain Dharma Mulya Tenggarong Seberang Tahun Ajaran 2016/2017”.

\section{METODOLOGI PENELITIAN}

\section{Desain Penelitian}

Penelitian ini adalah jenis penelitian tindakan kelas yang bertujuan untuk memperbaiki dan meningkatkan motivasi belajar anak dengan metode permainan dari bahan bekas pada Kelompok B di Kelompok BermainDharma Mulya Kecamatan Tenggarong Seberang Tahun Ajaran 2016/2017.

Arikunto (2006:131) menyatakan bahwa dalam pelaksanaan penelitian tindakan kelas terdapat dua jenis data yang dapat dikumpulkan oleh peneliti berupa data kuantitatif yang merupakan (nilai hasil belajar anak) yang dianalisis serta deskriptif dan data kualitatif yaitu data berupa informasi yang berbentuk kalimat untuk menggambarkan tingkat pemahaman terhadap suatu materi, dan sudut pandang anak terhadap metode pembelajaran yang baru. Penelitian tindakan kelas ini akan menggunakan teknik analisis statistik deskriptif yaitu berupa penilaian rata-rata dan penilaian keberhasilan belajar anak.

\section{Subjek Penelitian}

Penelitian ini dilaksanakan di Kelompok Bermain Dharma Mulya Jl. Sadewa RT. 12 Dusun Karya Harapan Desa Mulawarman Kecamatan Tenggarong Seberang Kabupaten Kutai Kartanegara Tahun Ajaran 2016/2017.

\section{Jadwal Penelitian}

Penelitian ini dilakukan pada bulan Februari 2017 dan yang akan diteliti sebanyak 30 siswa di Kelompok B, Kelompok Bermain Dharma Mulya Kecamatan Tenggarong Seberang Kabupaten Kutai Kartanegara Tahun Ajaran 2016/2017.

\section{Prosedur Penelitian}

Menurut Kemmis dan Mc. Taggart (1992:10) proses penelitian tindakan kelas merupakan daur ulang atau siklus yang dimulai dari aspek. (1) menyusun perencanaan, (2) melakukan tindakan sesuai rencana, (3) melakukan observasi terhadap tindakan, (4) melakuka refleksi yang berupa perenungan terhadap perencanaan, kegiatan tindakan dan hasil yang diperoleh. Jika ternyata tindakan perbaikan belum berhasil, maka akan terdapat siklus 2 d 3 yang langkah-langkahnya tetap sama sampai perbaikan berhasil dilakukan. Tahapan pelaksanaan tindakan tersebut dapat terlihat dalam diagram berikut: 


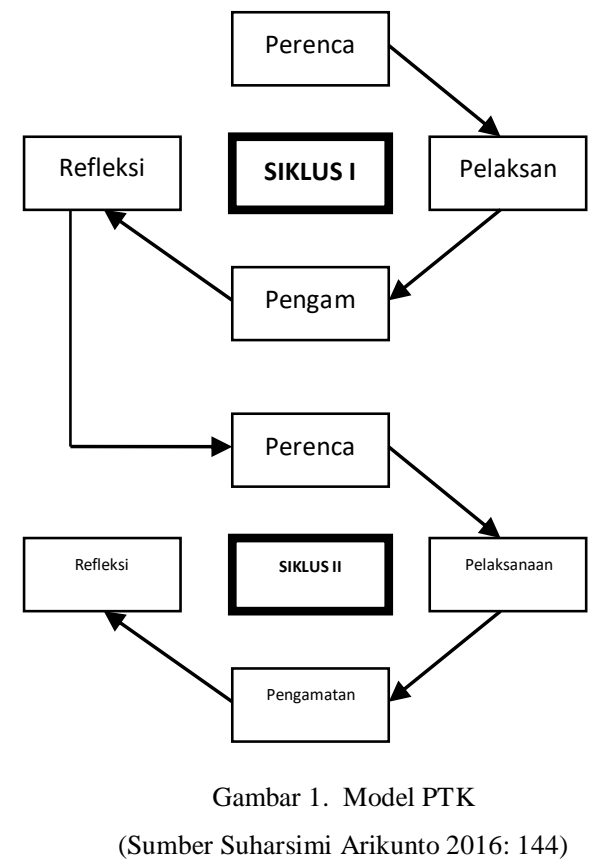

Observasi awal dilakukan oleh peneliti terhadap pembelajaran, studi pendahuluan ini dilakukan untuk mengetahui permasalahan yang dihadapi guru (peneliti) dan siswa dalam pembelajaran. Kegiatan ini dilaksanakan dengan cara mencari dan menemukan permasalahan dalam pembelajaran melalui pemberian motivasi belajar anak dengan metode permainan, mengamati kondisi siswa dalam pelaksanaan pembelajaran di kelas dan penyelenggaraan evaluasi. Berdasarkan hasil studi pendahuluan tersebut dapat disimpulkan bahwa (1) peneliti mengalami kesulitan dalam merencanakan, melaksanakan dan menilai pembelajran, (2) strategi yang diinginkan belum tepat, (3) guru (peneliti) belum dapat menumbuhkan kreativitas siswa dalam proses pembelajara. Dengan hasil studi pendahuluan tersebut, peneliti merumuskan permasalahan yang akan diingat sebagai permasalahan penelitian yakni peningkatan pembelajaran melalui motivasi. Setelah ini mengadakan kesepakatan dengan teman sejawat mengenai alternatif tindakan untuk dilaksanakan dalam pembelajaran melalui motivasi belajar anak dengan metode permainan dari bahan bekas.

\section{Tahapan Perencanaan}

1. Menyusun rancangan tindakan berupa Model Satuan Penelitian (MSP), meliputi (a) tujuan pembelajaran, (b) kegiatan belajar mengajar dan, (c) evaluasi.

2. Menyusun indikator, deskriptor dan kriteria pencapaian dalam pembelajaran.

3. Menyusun instrument untuk menggali data berupa : pedoman observasi, pedoman wawancara, format catatan lapangan, dan dokumentasi.

Dalam tahapan ini yang dilaksanakan guru adalah :

a. Membuat rencana kegiatan mingguan (RKM)

b. Membuat rencana kegiatan harian $(\mathrm{RKH})$ 
c. Menyediakan media pembelajaran yaitu alat dan bahan

d. Membuat Observasi siswa

e. Membuat hasil belajar siswa

\section{Tahapan Pelaksanaan Tindakan}

Tahapan ini merupakan langkah pelaksanaan rencana yang telah disusun oleh peneliti. Adapun kegiatan yang dilakukan dalam tahap pelaksanaan ini adalah sebagai berikut :

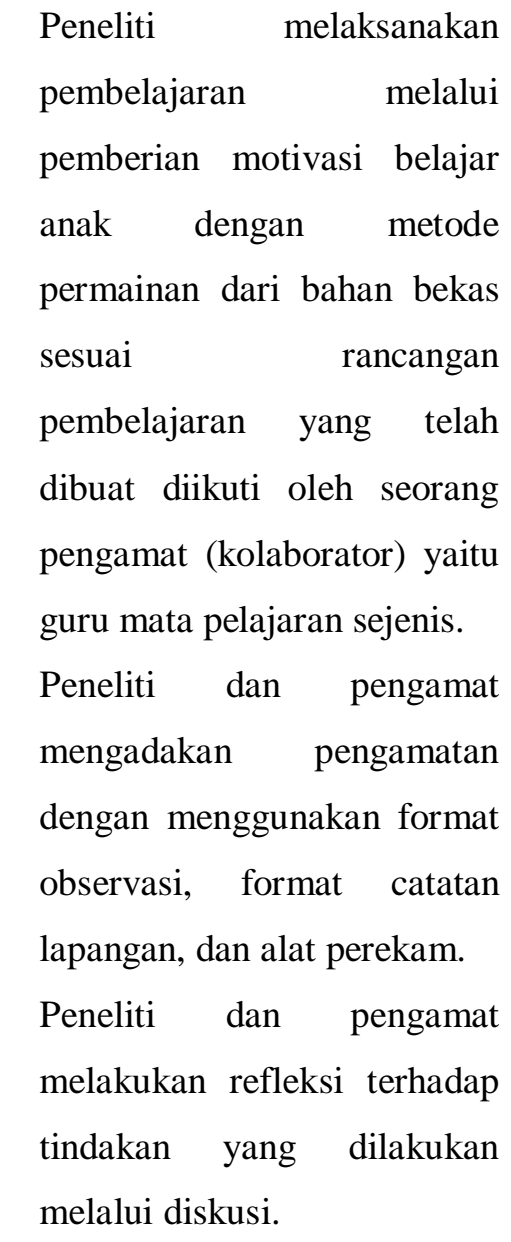

Fokus tindakan berupa pembelajaran melalui pemberian motivasi belajar anak dengan metode permainan dari bahan sisa.Hasil tindakan pada siklus I digunakan sebagai dasar perbaikan pada siklus berikutnya, sampai menghasilkan tindakan yang sesuai dengan tujuan yang diinginkan. Tahapan yang dirancang pada tahap pelaksanaan :

Opening Pagi :

Anak disiapkan dalam barisan, guru menyapa dan memberi salam kemudian masuk kedalam kelas.

Kegiatan awal ( \pm 30 menit)

Kegiatan awal di Kelompok Bermain Dharma Mulya yaitu anak-anak berdoa sebelum melakukan kegiatan, kemudian menyanyikan lagu anak-anak sesuai tema dan guru akan menjelaskan kegiatan yang akan dilakukan hari ini yaitu tema binatang.

Kegiatan inti $( \pm 60$ menit)

Kegiatan inti berlangsung kurang lebih 60 menit. Guru membagi anak dalam lima kelompok tediri dari enam anak kemudian guru menjelaskan nama permainan dan cara bermain. Kemudian guru memberikan kesempatan kepada salah satu kelompok untuk melakukan permainan tersebut.

Istirahat ( \pm 30 menit)

Anak-anak cuci tangan dan berdoa sebelum dan sesudah makan kemudian makan bersama.

\section{Kegiatan akhir $( \pm 30$ menit $)$}

Kegiatan diisi dengan recalling atau mengingat kembali seluruh aktivitas yang telah dilakukan anak, kegiatan ini 
dilakukan dengan percakapan serta diselingi dengan nyanyian atau tepuk yang sesuai dengan tema.

\section{Pengamatan (Observasi)}

Pada tahap ini, kegiatan diarahkan pada pengamatan dan mendokumentasikan segala sesuatu yang berkaitan dengan tindakan yang dilakukan. Kegiatan ini mencakup pengamatan mengenai kegiatan siswa dan guru selama proses pembelajaran melalui pemberian motivasi belajar anak dengan metode permainan dari bahan bekas. Peran peneliti adalah sebagai guru pendamping dan pengamat pelaksanaan tindakan yang dilakukan guru dalam pembelajaran melalui pemberian motivasi belajar anak dengan metode permainan dari bahan bekas.Pengamatan dilakukan menggunakan lembar instrument pengamtan yang telah dirancang sebelumnya melalui bentuk dokumentasi seperti catatan lapanga, dan alat perekam data.Pengamatn dilakukan secara terus menerus terhadap semua indikator yang tampak berkenaan dengan dua penelitian.Hal ini dilakukan untuk menjaga kemungkinan terdapat penyimpangan-penyimpangan dalam pembelajaran yang tidak direncanakan sebelumnya. Dengan demikian, tujuan untuk mengetahui proses dan peristiwa yang terjadi dalam pembelajaran melalui pemberian motivasi belajar anak dengan metode permainan dari bahan bekas.

\section{Refleksi}

Refleksi dilakukan oleh peneliti dan pengamat berdasarkan temua-temuan yang diperoleh selama pengamatan dalam pembelajaran.Refleksi dimaksudkan sebagai upaya balikan terhadap semua kegaitan yang terjadi selama proses pembelajaran. Pada tahap ini, kegiatan difokuskan pada menganalisis dan menyimpulkan data, kegiatan ini menghubungkan antar peristiwa yang terjadi di dalam kelas selama proses pembelajaran dengan kriteria yang sesuai. Hasil yang diperoleh pada kegiatan refleksi adalah informasi tentang apa yang terjadi dan apa yang diperlukan selanjutnya. Dari hasil refleksi ini diharapkan dapat diungkapkan dan dirumuskan kesempatan, peluang, hasil yang dicapai, keterbatasan, hambatan-hambatan, konsekuensi, implikasi, dan simpulan temuan.Kesimpulan yang diperoleh dari siklus I dijadikan dasar pijakan untuk merevisi rencana umum penelitian, penyusunan rencana yang lebih terfokus, dan intervensi tindakan terfokus pada siklus berikutnya. Dengan cara demikian pada siklus II kemudian tindakan berhenti jika proses pembelajaran telah menunjukkan kemajuan yang berarti. 


\section{Siklus 1}

Pada siklus I di awali dengan tahapan perencanaan yaitu membuat RKM dan RKH sesuai dengan tema pembelajaran yang ingin disampaikan.Pelaksanaan siklus 1 dilaksanakan dengan menyiapkan permainan yang digunakan pada tahapan observasi dengan menggunakan lembaran pengamatan untuk anak.

\section{Siklus 2}

Pada siklus 2 diawali dengan tahapan perencanaan yaitu membuat RKM dan RKH sesuai dengan tema pembelajaran tindakan siklus 2 dilaksanakan dengan menggunakan permainan yang lebih menarik. Observasi siklus 2 dilaksanakan melalui kegiatan evaluasi dan identifikasi masalah yang terjadi pada pelaksanaan tindakan siklus 2 untuk memperbaiki pada siklus selanjutnya yaitu siklus 3

\section{Siklus 3}

Tahapan perencanaan siklus 3 penelitian membuat RKM dan RKH sesuai dengan tema untuk pelaksanaan tindakan siklus 3 menggunakan lembaran pengamatan anak.Tahapan refleksi pada siklus 3 merupakan kegiatan evaluasi dan penarikan kesimpulan mengenai keberhasilan tindakan siklus.Apabila permasalahan sudah dapat teratasi pada siklus 3 maka penelitian tidak perlu dilanjutkan.

\section{Instrumen Penelitian}

\section{Lembar Observasi}

Lembar Observasi digunakan untuk mengamati dan mencatat hasil pengamatan tentang kegiatan pembelajaran anak.

\section{Teknik Pengumpulan Data}

Untuk memperoleh data dalam penelitian ini digunakan instrumentinstrumen utama penelitian ini adalah penelitian sendiri.Dalam pengumpulan data, peneliti berperan sebagai perencana tindakan, pengumpul data yang lengkap, pemakna data dan pelapor temuan data. Untuk mendapatkan data yang lengkap, peneliti menggunakan instrument pengumpul data sebagai instrument penunjang yaitu : format (pedoman) lembar observasi (pengamatan), lembar pedoman, catatan lapangan dan lembar wawancara.

\section{Teknik Analisi Data}

Analisi data dalam penelitian tindakan di dasarkan pada momen refleksi penelitian tindakan. Refleksi penelitian tindakan bertujuan untuk memahami proses, persoalan dan kendala nyata yang muncul dalam tindakan. Data yang terkumpul dalam penelitian tindakan ini dianalisis melalui proses reduksi data, penyajian data, pemaknaan data dan penarikan kesimpulan. 
Untuk mencari nilai rata-rata,

mencari presentase dengan

menggunakan rumus :

$$
x=\frac{\sum \mathrm{X}}{\sum \mathrm{N}} \mathrm{X} 100
$$

Dengan $X=$ Nilai rata-rata

$\sum X=$ Jumlah semua nilai siswa

$\sum \mathrm{N}=$ Jumlah siswa

Mencari keberhasilan siswa dengan rumus :

$P=\frac{\text { Jumlah siswa yang berhasil }}{\text { Jumlah Siswa }} \times 100$

\section{Indikator Penilaian}

Adapun indikator yang digunakan adalah sebagai berikut :

1. Antusias anak dalam melakukan kegiatan permainan

2. Perhatian anak dalam melakukan kegiatan permainan

3. Keaktifan anak dalam bertanya dan menjawab pertanyaan

4. Memahami peraturan dan disiplin

Kriteria menurut Suharsini Arikunto (2005:44) lima kategori predikat tersebut yaitu :

1. Kriteria Sangat Baik apabila nilai yang di peroleh anak antara $81 \%$ $100 \%$.

2. Kriteria Baik apabila nilai yang di peroleh anak antara $61 \%-80 \%$.

3. Kriteria Cukup apabila nilai yang di peroleh anak antara 41\%-60\%.

4. Kriteria Kurang apabila nilai yang di peroleh anak antara $21 \%-40 \%$.
5. Kriteria Kurang Sekali, apabila nilai yang di peroleh anak antara 0\%-20\%.

Table 1. Keterangan Rentang Prosentase

\begin{tabular}{|l|l|c|l|}
\hline No & $\begin{array}{l}\text { Rentang } \\
\text { Prosentase }\end{array}$ & Kriteria & Kategori \\
\hline 1 & $81-100$ & 5 & Baik sekali \\
\hline 2 & $61-80$ & 4 & Baik \\
\hline 3 & $41-60$ & 3 & Cukup \\
\hline 4 & $21-40$ & 2 & Kurang \\
\hline 5 & $0-20$ & 1 & $\begin{array}{l}\text { Kurang } \\
\text { sekali }\end{array}$ \\
\hline
\end{tabular}

\section{Indikator Keberhasilan}

Kriteria keberhasilan dinyatakan berhasil minimal $85 \%$ dari total jumlah anak. Jumlah anak yang diteliti sebanyak 30 anak, berarti sebanyak 26 anak atau lebih yang memperoleh kriteria nilai 5 (baik sekali).

Persentase Keberhasilan anak secara umum pada meningkatkan motivasi belajar anak melalui metode permainan dan bahan bekas adalah jumlah anak yang berhasil dibagi jumlah anak seluruhnya 30 dan dikali 100\% dari hasil tersebut maka dapat diketahui tingkat keberhasilan anak dalam meningkatkan motivasi belajar anak melalui metode permainan dari bahan bekas apabila jumlah anak yang berhasil dengan kriteria 4 dengan kategori baik dan 5 dengan kategori baik sekali maka dengan motivasi pembelajaran anak melalui metode permainan dan bahan bekas dinyatakan berhasil. 


\section{TEMUAN DAN PEMBAHASAN}

\section{Temuan}

\section{Kondisi Awal Penenlitian Sebelum}

\section{Tindakan}

Dari pengamatan awal yang diperoleh melalui lembar observasi mengenai motivasi belajar anak usia 5-6 tahun di Kelompok Bermain Dharma Mulya tahun pelajaran 2016-2017 semester 1 menunjukkan bahwa dari 30 anak hanya ada 6 anak (20\%) memiliki motivasi belajar dalam kategori baik, dan sisanya 24 anak (80\%) belum memiliki motivasi belajar dengan baik.

Dari data lembar observasi pada pengamatan awal tidak ada satupun yang mendapat nilai sangat baik, sabagaimana dalam tabel berikut ini :

Tabel 2. Lembar Observasi Peningkatan Motivas

\begin{tabular}{|c|c|c|c|c|c|c|}
\hline \multicolumn{7}{|c|}{ Belajar Anak Pra siklus } \\
\hline \multirow{3}{*}{$\begin{array}{l}\mathrm{N} \\
\mathrm{o}\end{array}$} & \multirow{3}{*}{$\begin{array}{c}\text { Aspek yang } \\
\text { dinilai }\end{array}$} & \multicolumn{5}{|c|}{ Skor yang dicapai } \\
\hline & & 1 & 2 & 3 & 4 & 5 \\
\hline & & \multicolumn{5}{|c|}{$\%$} \\
\hline 1. & $\begin{array}{l}\text { Antusias anak } \\
\text { dalam melakukan } \\
\text { kegiatan permainan }\end{array}$ & $\begin{array}{l}33, \\
3\end{array}$ & $\begin{array}{l}26, \\
7\end{array}$ & 20 & 20 & $\mathbf{0}$ \\
\hline 2. & $\begin{array}{l}\text { Perhatian anak } \\
\text { dalam melakukan } \\
\text { kegiatan permainan }\end{array}$ & $\begin{array}{l}26, \\
7\end{array}$ & 40 & $\begin{array}{l}13 \\
, 3\end{array}$ & 20 & $\mathbf{0}$ \\
\hline 3. & $\begin{array}{l}\text { Keaktifan anak } \\
\text { bertanya dan } \\
\text { menjawab } \\
\text { pertanyaan }\end{array}$ & 40 & $\begin{array}{l}26, \\
7\end{array}$ & $\begin{array}{l}13 \\
, 3\end{array}$ & 20 & $\mathbf{0}$ \\
\hline 4. & $\begin{array}{l}\text { Memahami } \\
\text { peraturan dan } \\
\text { disiplin }\end{array}$ & 20 & 40 & 20 & 20 & $\mathbf{0}$ \\
\hline \multicolumn{2}{|c|}{ Jumlah skor 4 dan 5} & 30 & $\begin{array}{l}33, \\
3\end{array}$ & $\begin{array}{l}16 \\
, 6\end{array}$ & 20 & $\mathbf{0}$ \\
\hline \multicolumn{6}{|c|}{ Nilai ketuntasan pra siklus } & 20 \\
\hline
\end{tabular}

Berdasarkan hasil pengamatan awal peningkatan motivasi anak sebelum melakukan tindakan adalahanak dengan skor 1 terdapat $30 \%$, skor 2 terdapat $33,3 \%$, skor 3 terdapat $16,6 \%$ dan skor 4 terdapat $20 \%$, maka nilai ketuntasan motivasi belajar anak pada pra siklus adalah 20\% dan pada pengamatan awal tidak ada satu anakpun yang mendapat skor 5 (baik sekali).

Penelitian ini dilakukan pada bulan Februari 2017 dan yang diteliti sebanyak 30 siswa di Kelompok B, Kelompok Bermain Dharma Mulya Kecamatan Tenggarong Seberang Kutai Kartanegara Tahun Pelajaran 2016/2017. Penelitian tindakan kelas merencanakan 2 siklus, dalam satu siklus tiga kali pertemuan.Apabila telah melakukan 2 siklus. Apabila dalam satu siklus peningkatan motivasi anak sudah mencapai indikator keberhasilan minimal $80 \%$, maka penelitian tidak berlanjut ke siklus selanjutnya, namun apabila dalam siklus 2 peningkatan motivasi anak belum mencapai indikator keberhasilan, dengan demikian penelitian berlanjut ke siklus lanjutan yaitu siklus 3 .

\section{Deskripsi Hasil Penelitian}

Penenlitian ini adalah penelitian deskripsi kuantitatif, yaitu mendeskrispsikan temuan-temuan yang ada pada proses pembelajaran berlangsung. Data kuantitatif akan diuji menggunakan rumus sebagai berikut: 
$x=\frac{\sum \mathrm{X}}{\sum \mathrm{N}} \mathrm{X} 100$

Dengan $X=$ Nilai rata-rata

$\sum X=$ Jumlah semua nilai siswa

$\sum \mathrm{N}=$ Jumlah siswa

Untuk mencari keberhasilan siswa dengan rumus :

$P=\frac{\text { Jumlah siswa yang berhasil }}{\text { Jumlah Siswa }}$ X 100

\section{Hasil pengamatan siklus 1}

Berdasarkan hasil pengamatan persentase keaktifan anak bertanya dan menjawab pertanyaan mencapai persentase terendah. Hal ini dikarenakan ketika anak asyik membuat permainan dari bahan bekas, anak-anak merasa senang dan ingin segera menyelesaikan pembuatan mainan dari bahan bekas.

Dari hasil pengamatan siklus 1 pertemuan 1, 2 dan 3 maka rekapitulasi peningkatan motivasi belajar anak dapat dilihat dalam tabel berikut ini :

Tabel 3. Data Rekapitulasi Peningkatan Motivasi Belajar Anak Melalui Siklus 1

\begin{tabular}{|c|l|c|c|c|c|}
\hline No. & $\begin{array}{l}\text { Aspek yang } \\
\text { dinilai }\end{array}$ & P 1 & P 2 & P3 & $\begin{array}{c}\text { Nilai } \\
\text { rata- } \\
\text { rata }\end{array}$ \\
\hline 1. & $\begin{array}{l}\text { Antusias anak } \\
\text { dalam melakukan } \\
\text { kegiatan } \\
\text { permainan }\end{array}$ & 33, & 46, & 60 & $\begin{array}{c}46,3 \\
\%\end{array}$ \\
\hline 2. & $\begin{array}{l}\text { perhatian anak } \\
\text { dalam melakukan } \\
\text { kegiatan } \\
\text { permainan, }\end{array}$ & 40 & 46, & 66, & $51 \%$ \\
\hline 3. & $\begin{array}{l}\text { keaktifan anak } \\
\text { bertanya dan } \\
\text { menjawab } \\
\text { pertanyaan }\end{array}$ & 33, & 40 & 53, & 42,2 \\
& & & $3 \%$ & \\
\hline 4. & $\begin{array}{l}\text { Memahami } \\
\text { peraturan dan } \\
\text { disiplin }\end{array}$ & 36, & 53, & 56, & 48,9 \\
\hline \multicolumn{5}{|l|}{$\begin{array}{l}\text { Nilai ketuntasansiklus 1 } \\
7 \%\end{array}$} \\
\hline
\end{tabular}

Berdasarkan hasil tabel 8, nilai ketuntasan peningkatan motivasi belajar anak pada siklus 1 adalah 47\%, dengan kategori cukup. Peningkatan motivasi belajar anak semakin meningkat, namun belum mencapai indikator yang ditentukan, untukmemperbaiki kelemahan penelitian ini, maka penelitian melanjutkan penelitian siklus

\section{Hasil Pengamatan Siklus 2}

Setelah dilakukan pengamatan hasil belajar anak melalui permainan dengan bahan bekas sudah memperoleh peningkatan Antusias anak dalam melakukan kegiatan permainan.Berdasarkan tabel 11, peningkatan motivasi belajar anak pada siklus 2 pertemuan ke-3 jumlah anak dengan skor 4 dan 5 adalah : antusias anak dalam melakukan kegiatan permainan $90 \%$, perhatian anak dalam melakukan kegiatan permainan 93,3\%, keaktifan anak bertanya dan menjawab pertanyaan $90 \%$ dan memahami peraturan dan disiplin 93,3\%, maka nilai ketuntasan peningkatan motivasi belajar anak pada siklus 2 pertemuan ke-3 adalah 90,8\%, dengan kategori baik sekali.

Hasil pengamatan siklus 2 pertemuan 1,2 dan 3 mengalami peningkatan sebagaimana dalam tabel berikut ini : 
Tabel 4. Data Rekapitulasi Peningkatan Motivasi Belajar Anak Melalui Permainan dengan Bahan Bekas

\begin{tabular}{|c|c|c|c|c|c|}
\hline $\begin{array}{l}\text { No } \\
\text {. }\end{array}$ & $\begin{array}{l}\text { Aspek yang } \\
\text { dinilai }\end{array}$ & P1 & $\begin{array}{l}\mathrm{P} \\
2\end{array}$ & P3 & $\begin{array}{l}\text { Nilai } \\
\text { rata- } \\
\text { rata }\end{array}$ \\
\hline 1. & $\begin{array}{l}\text { Antusias anak } \\
\text { dalam melakukan } \\
\text { kegiatan } \\
\text { permainan }\end{array}$ & $\begin{array}{l}76, \\
7 \%\end{array}$ & $\begin{array}{l}83 \\
, 3 \\
\%\end{array}$ & $\begin{array}{l}90 \\
\%\end{array}$ & $\begin{array}{c}83,3 \\
\%\end{array}$ \\
\hline 2. & $\begin{array}{l}\text { perhatian anak } \\
\text { dalam melakukan } \\
\text { kegiatan } \\
\text { permainan, }\end{array}$ & $\begin{array}{l}73, \\
3 \%\end{array}$ & $\begin{array}{l}86 \\
, 7 \\
\%\end{array}$ & $\begin{array}{l}93,3 \\
\%\end{array}$ & $\begin{array}{c}84,4 \\
\%\end{array}$ \\
\hline 3. & $\begin{array}{l}\text { keaktifan anak } \\
\text { bertanya dan } \\
\text { menjawab } \\
\text { pertanyaan }\end{array}$ & $\begin{array}{l}76, \\
7 \%\end{array}$ & $\begin{array}{l}90 \\
\%\end{array}$ & $\begin{array}{l}90 \\
\%\end{array}$ & $\begin{array}{c}85,6 \\
\%\end{array}$ \\
\hline 4. & $\begin{array}{l}\text { Memahami } \\
\text { peraturan dan } \\
\text { disiplin }\end{array}$ & $\begin{array}{l}80 \\
\%\end{array}$ & $\begin{array}{l}90 \\
\%\end{array}$ & $\begin{array}{l}96,7 \\
\%\end{array}$ & $89 \%$ \\
\hline \multicolumn{5}{|c|}{ Nilai } & $\begin{array}{c}85,6 \\
\%\end{array}$ \\
\hline
\end{tabular}

\section{Sumber data penelitian 2017}

Berdasarkan tabel 4, peningkatan motivasi belajar pada anak pada siklus 2 meningkat, dan mencapai nilai ratarata $85,2 \%$.Dari hasil penelitian tindakan kelas siklus 1 dan 2 hal ini menyatakan bahwa permainan dengan menggunakan bahan bekas berhasil untuk meningkatkan motivasi belajar anak, dan penelitian tidak dilanjutkan pada siklus 3 .

Hal ini dapat dilihat dari persentase peningkatan motivasi belajar anak pada siklus 1 dan siklus 2.Bahwa permainan dengan bahan bekas membuat anak senang, tertarik dan aktif bertanya. Sebagimana pada tabel rekapitulasi berikut ini :
Tabel 5. Data rekapitulasi peningkatan motivasi belajar

\begin{tabular}{|l|l|c|c|}
\multicolumn{4}{|c|}{ anak melalui permainan dengan bahan bekas } \\
\hline No. & Aspek yang dinilai & $\begin{array}{c}\text { Siklus } \\
1\end{array}$ & Siklus 2 \\
\hline 1. & $\begin{array}{l}\text { Antusias anak } \\
\text { dalam melakukan } \\
\text { kegiatan permainan }\end{array}$ & $46,3 \%$ & $83,3 \%$ \\
\hline 2. & $\begin{array}{l}\text { perhatian anak } \\
\text { dalam melakukan } \\
\text { kegiatan permainan, }\end{array}$ & $51 \%$ & $84,4 \%$ \\
\hline 3. & $\begin{array}{l}\text { keaktifan anak } \\
\text { bertanya dan } \\
\text { menjawab } \\
\text { pertanyaan }\end{array}$ & $42,2 \%$ & $85,5 \%$ \\
\hline 4. & $\begin{array}{l}\text { Memahami } \\
\text { peraturan dan } \\
\text { disiplin }\end{array}$ & $48,9 \%$ & $89 \%$ \\
\hline Nilai ketuntasan & $47 \%$ & $85,6 \%$ \\
\hline
\end{tabular}

Hasil peningkatan motivasi belajar anak melalui permainan dari bahan bekas pada pra siklus, siklus 1 hingga siklus 2 dapat dilihat pada grafik berikut ini :

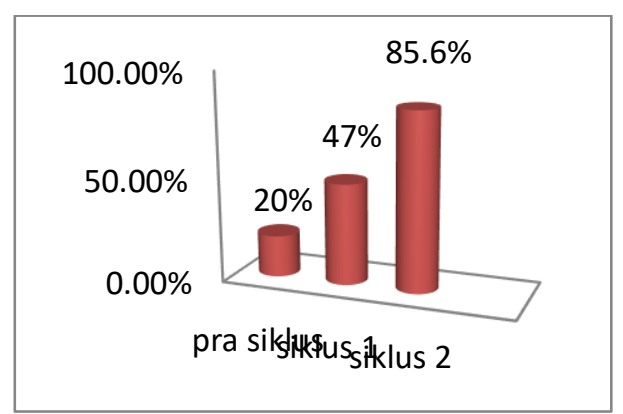

Grafik 1. Peningkatan Motivasi Belajar antar Siklus

\section{Pembahasan}

Proses belajar, motivasi, sangat diperlukan sebab seorang yang tidak mempunyai motivasi dalam belajar. Tidak akan mungkin melakukan aktivitas belajar. Hal ini merupakan pertanda bahwa sesuatu yang akan dikerjakan itu tidak menyentuh kebutuhannya. Pemikiran tersebut sejalan dengan pendapat Maslow 
(1930:1970) sangat percaya bahwa tingkah laku manusia dibangkitkan dan di arahkan oleh kebutuhan-kebutuhan tertentu seperti kebutuhan fisiologis, rasa aman, rasa cinta, penghargaan aktualisasi diri, mengetahui dan mengerti.

Sedangkan motivasi yang ditingkatkan pada penelitian ini adalah suatu proses interaksi atau dialog dari antar interaksi pada dasarnya setiap guru mengharapkan agar para peserta didiknya dapat memperoleh hasil belajar yang baik melalui proses kegiatan belajar mengajar. Dengan memperoleh hasil belajar yang baik diharapkan setiap anak merubah tingkah lakunya sesuai dengan tujuan pembelajaran dan tujuan pendidikan.

Berdasarkan pengertian motivasi belajar pada anak, pada penelitian ini guru memanfaatkan bahan bekas untuk diolah menjadi bentuk baru, lebih menarik dan mudah dibuat oleh anakanak, untuk digunakan sebagai alat permainan anak.

Dalam penelitian ini anak-anak diajak bermain dengan menggunakan alat permainan yang dibuat sendiri oleh anak secara berkelompok, dengan bermain anak-anak tidak menyadari bahwa aktivitas yang dilakukan saat bermain adalah belajar, pada saat membuat alat permainan anak-anak akan termotivasi untuk bertanya, menjawab pertanyaan, dan antusias anak dalam melakukan kegiatan.

Metode ini di arahkan agar tujuan belajar dapat dicapai secara efesien dalam suasana gembira meskipun membahas hal-hal yang sulit atau berat. Sebaiknya permainan digunakan sebagai bagian dari proses belajar. Bukan hanya mengisi waktu kosong atau sekedar permainan, permainan sebaiknya dirancang menjadi suatu "aksi" atau kejadian yang dialami sendiri oleh peserta, kemudian ditarik dalam proses refleksi untuk menjadi hikmah yang mendalam (prinsip, nilai atau pelajaranpelajaran) wilayah perubahan yang dipengaruhi adalah ramah, sikap, dan nilai.

\section{PENUTUP}

\section{Kesimpulan}

Berdasarkan hasil penelitian yang telah dilakukan, maka dapat ditarik kesimpulan bahwa melalui permainan dengan bahan bekas pada anak kelompok B di Kelompok Bermain Dharma Mulya Tenggarong Seberang Tahun Pembelajaran 2016-2017 motivasi belajar anak meningkat, dengan aspek penilaian sebagai berikut :

1. Antusias anak dalam melakukan kegiatan permainan 
2. Perhatian anak dalam melakukan kegiatan permainan

3. Keaktifan anak bertanya dan menjawab pertanyaan

4. Memahami peraturan dan disiplin

Hal tersebut dapat dilihat dari hasil penelitian yang telah dilakukan melalui beberapa tindakan siklus 1 dan siklus 2 dengan 3 kali pertemuan berdasarkan seluruh pembahasan serta analisa yang didapat berdasarkan pada tabel rekapitulasi. Peningkatan motivasi anak antar siklus terus meningkat.

\section{Saran}

Berdasarkan pada latar belakangmasalah yang diuraikan pada bab I, serta data yang diperoleh setelah melakukan penelitian tindakan kelas, maka peneliti menyarankan hal-hal sebagai berikut :

1. Bagi kepala $\mathrm{KB}$ diharapkan memberikan motivasi kepada guru agar lebih baik dalam membuat perangkat mengajar dalam menentukan metode, media dan alat peraga yang tepat guna, mudah dipergunakan bagi anak didik.

2. Bagi para pendidik/guru agar selalu meningkatkan mutu dalam kegiatan belajar dan mengajar, juga aktif dan kreatif dalam menyiapkan media pembelajaran yang mampu menarik minat belajar anak dalam meningkatkan motivasi belajar anak.
3. Bagi anak. Mengembangkan kemampuan berfikir anak, menumbuhkan daya kreativitas dan membantu anak untuk mampu bersosialisasi dengan teman, guru dan lingkungan.

\section{DAFTAR PUSTAKA}

Anonim. 2007. Pedoman Blockgrank Penelitian Tindakan Kelas. Departemen Pendidikan Nasional.Direktorat Jendral Penelitian Mutu Pendidikan dan Tenaga Kependidikan. Jakarta:Balai Pustaka

Ardial,Drs., M.Si. 2005. Bagaimana Mengetahui Kemampuan Anak. Jakarta :Metro Press.

Arikunto, Suharsimi, Prof.Dr. 2016. Penelitian Tindakan Kelas. Jakarta: Bumi Aksara.

Asmani, Jamal Ma'mur. 2007. Kompetensi Menyenangkan dan Progfesional. Yogyakarta: Power Books.

Dohnson, Elaine B. 2009. Constektual Teaching and Learning. Menjadikan Kegiatan Belajar dan Mengajar Bermakna. Bandung :MK.

Firdaus, Ahmad Zuldhi, S.Sos.I, M.Pd. 2010.Guru Idola. Yogyakarta: GEN-K Publisher

Djamarah,Syaiful Bahri. 2008. Psikologi Belajar. Jakarta: Rineka Cipta

Gagne, Belajar dan Pembelajaran (diadaptasi dari Bell Gredler). 1991. Jakarta: Rineka Cipta.

Herbert, Perti. 1986. Motivasi and Research. California: Publisher Company Piaget.tan Teoritas dan Praktis Meraih Keberhasilan Belajar. Jakarta: Rineka

Idri, Shaafat. 2009. Optimized Learning Strategy. Pendekatan dan Praktis Meraih Keberhasilan Belajar di Sekolah.Jakarta: Prestsi Pustaka

Imam, Musbikin. 2010. Buku Pintar PAUD. Jakarta :Rineka Cipta

Kamus Besar Bahasa Indonesia http://kbbi.web.id/2 28 Oktober 2016 
Koeswara.E.1989. Motivasi.Bandung Angkasa

Panduan Penulisan Skripsi PG PAUD. 2015.

Universitas Widya Gama Mahakam Samarinda

Mujiono, Drs. 2009. Belajar dan Pembelajaran.Departemen Pendidikan dan Kebudayaan. Jakarta: Rineka Cipta. 